\title{
APPLICATION OF MOBILE MAPPING SISTEMS FOR THE PURPOSE OF PRODUCING THE CADASTRE OF TRAFFIC SIGNALING
}

\author{
Miroslav Kuburić ${ }^{1}$ \\ Siniša Delčev ${ }^{2}$ \\ Vukan Ogrizović ${ }^{3}$ \\ Stefan Miljković 4
}

UDK: 528.4:004.7

DOI:10.14415/konferencijaGFS2017.094

Summary: The paper presents the system for mobile mapping (MMS), which usage increases more and more. A description and features are given using the Topcon IP-S2 as an example. After theoretical concepts, methodology for using MMS in surveying and preparing catalogs of traffic signaling is demonstrated.

Keywords: Mobile Mapping System (MMS), GIS, data processing, point cloud

\section{INTRODUCTION}

Thanks to huge technological development in data collecting and processing, using GNSS, combined with inertial measurement units (IMU), several new devices appeared in the market. The devices can be used for solving various technical tasks regarding data collecting for mapping or GIS applications. Following permanent development of technical resources of GNSS/INS systems and advantage in data processing, the systems with impressive capabilities appear in the market. It is reflected in the speed of data collecting, data density (which increased the positioning accuracy), but also in decreasing the price of obtained data. Leading world manufacturers of MMS devices, like Topcon, Trimble, Novatel, Applanix, spend most of time in improving the system accuracy in the situations of GNSS signal loss. By integration of the two navigation technologies working complementary, MMS is capable, even in the case of GNSS signal loss, to quickly obtain a fixed solution and continue tracking. Then, achieved accuracy directly determines usage possibility of these systems, for selected applications.

\footnotetext{
${ }^{1}$ Miroslav Kuburić, dipl. geod. inž., Univerzitet u Novom Sadu, Građevinski fakultet Subotica, Kozaračka 2a, Subotica, Srbija, tel: +381 24554 300, e-mail: mkuburic@gf.uns.ac.rs

${ }^{2}$ Sniša Delčev, dipl. geod. inž., Univerzitet u Beogradu, Građevinski fakultet, Bul. kralja Aleksandra 73, Beograd, Srbija, tel: +381 113218 542, e-mail: delcev@grf.bg.ac.rs.

${ }^{3}$ Vukan Ogrizović, dipl. geod. inž., Univerzitet u Beogradu, Građevinski fakultet, Bul. kralja Aleksandra 73, Beograd, Srbija, tel: +381 113218 582, e-mail: vukan@ grf.bg.ac.rs.

${ }^{4}$ Stefan Miljković, dipl. geod. inž. - master, Univerzitet u Beogradu, Građevinski fakultet, Bul. kralja Aleksandra 73, Beograd, Srbija, tel: +381 64 4031006, e-mail: skiljk@live.com
} 
The MMS can be defined as a moving platform, with several integrated systems (or sensors) for continuous 3D mapping of the platform itself and geospatial data collecting, using one or more GNSS base stations. Three main measuring components comprise most of MMSs: GNSS, IMU or some other sensor for position calculation and the sensor(s) for collecting photos. That is how MMS presents integration of kinematic geodesy and digital photogrammetry, used for collecting data that would correctly describe spatial and/or physical characteristics of parts of the Earth's surface. The MMS is often understood as data collecting using a car, but any type of the moving sensor can be used - the car, a helicopter, an airplane, a satellite, but also people while moving.

\section{MOBILE MAPPING SYSTEM (MMS)}

MMS is a unique technology, which makes possible fast and efficient collecting of geospatial data, especially in urban environments, where the infrastructure changes rapidly and where it is not possible to quickly register all changes using classical surveying methods. This paper is about using MMS installed on vehicles.

\subsection{MMS parts}

Although there are differences between MMSs of different manufacturers, elements are, generally, the same. MMS consists of four main components (sensors): GNSS, INS, LIDAR, and a phorogrammetric camera. These sensors are mounted on the roofs of the vehicles with an auxiliary unit - odometer, fixed to the vehicle's tires, which, thanks to the technology development, can be replaced with a direct communication with an on-board computer of the vehicle. These units serve for determination of MMS position, as well as for geo-referencing the results from the sensors used for data collecting - the camera and the scanner.

GNSS provides precise positioning along the whole surveying route. Unfortunately, GNSS cannot be used in all environments, due to various influences to the measurement results: inappropriate satellite geometry, cycle slips, losses of lock, or interruptions that can appear during the vehicle maneuvers. Such conditions can arise in urban centers (due to high buildings) and along the roads where viaducts and tunnels interrupt the satellite signals. Besides that, it is necessary to know the correct relation between the antenna phase center and the other sensors. The phase center is not a physically materialized point, and it is not stable in space and time. Its position depends, mostly, on the satellite height, and varies with the change of the azimuth of the satellite signal. For the vertical component, the height, possible errors can be up to $10 \mathrm{~cm}$.

The other element of the navigation component is INS, which measures precisely linear acceleration and angular velocities. One of the advantages of INS is that the system is autonomous, because it does not relay to other sensors, compared to GNSS that receives the satellite signals. The main function of INS is determination of the camera orientation at the moment when a photo is taken. An additional feature can be used in positioning for resolving the GNSS losses of lock, cycle slip corrections, and for precise interpolation between two GNSS epochs. In a short time interval, INS gives a remarkable accuracy of positioning and navigating, but the errors accumulate with the time passed. 
There are two types of INS - in one system, the inertial unit always moves, while in the other, it is fixed to the vehicle. The usage of IMU fixed on the vehicle is very simple - the instrument consists of three gyroscopes used for measuring the angular movements and three accelerometers for measuring accelerations in three orthogonal axises in the inertial or in the fixed non-rotating system. IMU operation is based on the Newton's law:

$$
\vec{r}=\vec{a}+\vec{g}
$$

where $\vec{r}$ is a vector of the total inertial acceleration, $\vec{a}$ is the force vector, and $\vec{g}$ is the vector of the total gravitational acceleration. IMU does not measure the gravity field, so, for usage in navigation, information regarding gravity have to been provided by a system processor.

Measuring with the inertial system begins with a starting alignment, for estimating the starting position, velocity and behavior of the platform. The angular velocity can be integrated in time, because the changes in the vehicles slope are determined by measuring relatively to the starting orientation, assuming that movement and the velocity of the vehicle are already known. Special attention is paid to double integration in time, for obtaining position differences related to the starting point. That is why the position is dependent on time and the errors accumulate quickly.

Integrating GNSS with IMU makes possible the control of INS error accumulation. However, in a very dynamic environment of MMS, it is the best combination of the instruments for satisfying the requests for mapping accuracy.

Working together, GNSS and INS form a complementary system for position determination and for navigation. GNSS decreases the long term errors, that appear in the inertial system. When the GNSS receiver loses a connection with the satellites, INS helps in its reinitialization, when it connects to the satellites again. GNSS has relatively low speed of data collecting, usually $1 \mathrm{~Hz}$, while the registration with INS could be even 100 $\mathrm{Hz}$.

For positioning with the integrated GNSS/INS sensors, Kalman filters are used. The system comprises the measured vectors consisting of the slope, position, velocity, signal (accelerometer) and noise (gyroscope). The filter is used for prediction of the values of the observed vector. When the new measurements are made, the Kalman filter uses them for more precise prediction of the position vector. Since the Kalman filter is a mathematical model used for changing the observed vector, there are various filter types. There filters can contain 9 indicators of the navigational error, which describe the position, velocity and slope, together with 6 indications of IMU sensor errors (signal, noise,...). Other error sources can be added to this basic model.

The Kalman filters can model GNSS and INS sensor errors in the same time. The reference route is determined according to the measured data of the INS sensors, while GNSS data are used for updating the solution. The other way is using two Kalman filters working permanently, with only occasional mutual interaction. GNSS data passed the Kalman filter are used for position determination, and then for updating the Kalman filter.

A computer adapted for data collection manages the whole system. The most important characteristics of the computer used for these applications are capacity and the hard disk speed, but also performances of the processor and the graphic adapter, that should suffice high requirements. Standard serial and USB ports are used as the interfaces for communication between single components and for communication and data transfer between the computer and MMS. For digital cameras, special solutions are developed. 
Савремена достигнућа у грађевинарству 21. април 2017. Суботица, СРБИЈА

A number and way of placing the digital cameras depend on the application type for which the data is collected. It is useful to place cameras in such position that the photos make stereoscopic pairs, which allows stereoscopic measurements. For some applications, it is better to have the camera positions placed in opposite directions or orthogonal, which maximizes the coverage of the field view.

In the beginning of MMS development, scanning was performed with 3D laser scanners, that scanned the area around the vehicle only in the static mode, while the vehicle stays still, and then the digital cameras took photos. Now the systems with several scanners are used. They perform dynamic scanning of the field, while the vehicle moves.

\subsection{MMS Topcon IP-S2}

Topcon Corporation produces the systems adapted to the customer requests. Fig. 2 presents the version of the basic system configuration, mounted on the vehicle roof, on the movable support.
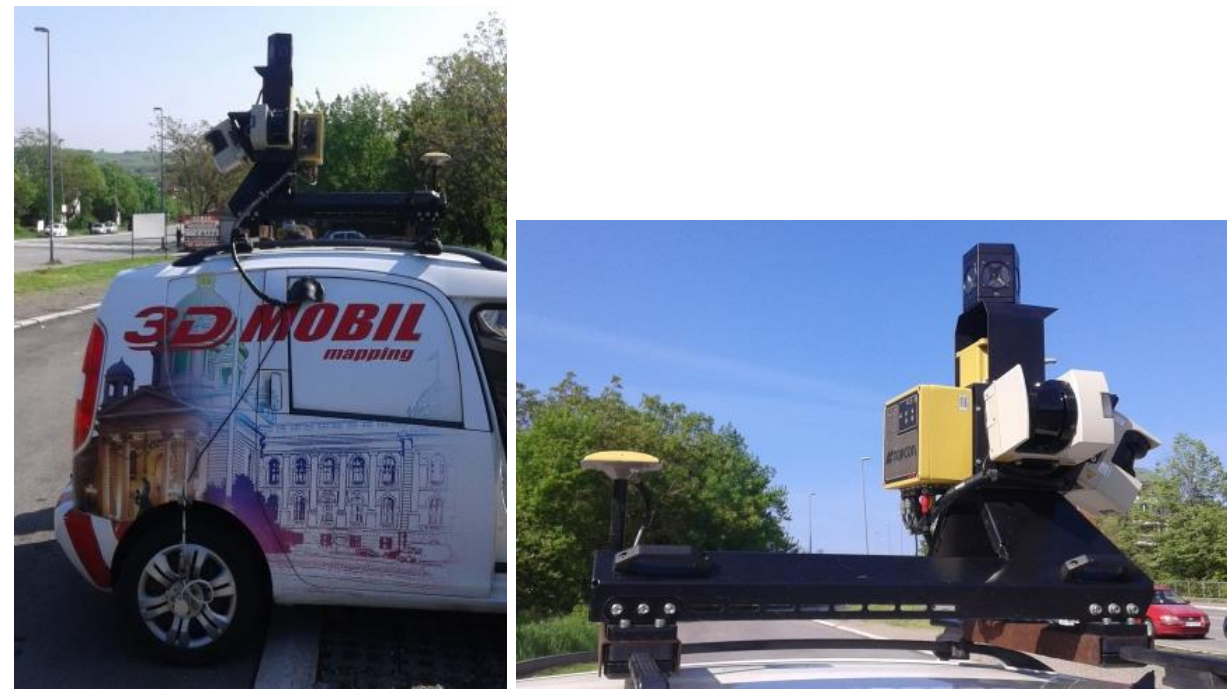

Figure 1. Topcon IP-S2 system (Geoput d.o.o.)

The base of this system is the calibrated construction IP S2 Cube, with a control unit IPS2 Box mounted to it, and connected with the computer by an Ethernet cable. The montage of the telescope system allows placing the equipment to the lower position, for easier storing when the system is not used. All other devices are connected with the control unit. The double frequency GNSS receiver can receive both GPS and GLONASS signals with the registration frequency up to $20 \mathrm{~Hz}$. Honeywell IMU, with the $100 \mathrm{~Hz}$ frequency and $1 \% \mathrm{~h}$ SNR of the gyroscope, belongs to the best devices in this category. For the applications with lower accuracy needs, the IMU based on MEMS (Micro-ElectroMechanical Systems) technology can be used. Precise velocity of MMS is determined by two odometers or connecting to the vehicle interface. The basic version of the IP-S2 
Contemporary achievements in civil engineering 21. April 2017. Subotica, SERBIA

system is equipped with the special spherical camera and three laser scanners. Two of them are turned to opposite sides (left and right), with the third one placed in front or back, depending on the configuration. Following the customer demands, up to six classical digital cameras and up to six laser scanners can be set. Sensor synchronization is kept by a clock with the internal accuracy of $15 \mathrm{~ns}$.

\section{DATA COLLECTION WITH TOPCON IP-S2 MMS}

The first step of the mobile mapping assumes data collecting in the area of surveying. The system is controlled by a web-based application, allowing the users to monitor the proper functioning of certain sensors and set their parameters. The parameters include mutual distances and orientation determined by calibration. For the digital cameras, it is possible to choose one of two regimes of exposure control - the first, based on equal time intervals, and second, used more frequently, based on equally passed distances. When all parameters for data collecting are set, and when data collecting for all sensors started, usually, it is necessary to wait some time before beginning the ride and static data collection. The static data (from GNSS) are needed for the process called the static adjustment, which can be understood as the method for calculating the starting values of IMU orientation. In practice, so called, kinematic adjustment is, also, used, where no static data is needed. In all cases, it is useful to complete both adjustments, at the beginning of the data collection. For the kinematic adjustment, it is recommended to drive in the manner that direction changes are as big as possible, in order to provide enough data for the correct estimation of the position and the orientation of the system. Starting of the data collection should always begin in the areas with good GNSS coverage, for providing high quality positioning. Wrong initialization of the process could lead to obtaining the wrong data, which, in that case, would have to be canceled and the measurements repeated from the beginning.

\section{GEO-REFERENCING CONCEPT}

The geo-referencing task is to use the surveyed coordinates for GIS, i.e., to obtain them in the appropriate coordinate system. Historically, when the photos were used for objects positioning, a set of Ground Control Points (GCP) on the Earth surface was needed. It is called indirect geo-referencing - the position of the photo is determined by aerotriangulation, using the concept of crossing the directions to the control points. Determination of the control points is an expensive phase which spends a large part of a project budget, depending on the location. For years, many tries are made in order to improve the accuracy of the external orientation parameters and reduce the number of needed GCPs, which was achieved by the GNSS receiver in the airplane. Photogrammetry airborne surveying could be realized without GCPs, but other sensors still need them. By integration of INS with GNSS, determination of all six external orientation parameters became possible.

The geo-coding component of MMS consists of three parts: a calibration module, the module for location/height and the stereo module. In the case of MMS, there are three, sometimes even more reference frames. The goal of surveying is to get the spatial locations 
of the objects in the real coordinates, whether state orthogonal, UTM, geodetic (latitude, longitude, height) coordinates, or in any other, Earth-fixed, system. This system is called the map frame ( $\mathrm{m}$-frame). The vehicle has its own reference frame called the body frame (b-frame). When INS is used, the b-frame is fixed to the inertial coordinate system. Finally, there is the sensor reference frame. Since the sensor is usually the camera, it can be call the camera frame (c-frame).

The geo-referencing process assumes picture transformation in 2D space, the c-frame, into the map plane, i.e., the $\mathrm{m}$-frame. The c-frame is in the local coordinate system, fixed to one of the cameras. The camera to object vector, $r^{c}$, is transformed to the vector from the map system origin to the object, $r_{i}^{m}$. This is expressed as:

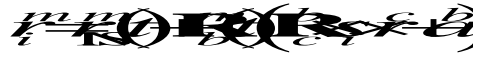

where:

$r_{i}^{m} \quad$ - coordinate of the $i$ point vector (in the $\mathrm{m}$-frame),

$r_{\text {INS }}^{m}(t)$ - time-dependent vector defined from the map coordinate origin to INS (or GNSS) (in the m-frame),

$t$ - time exposure of the snapshot,

$\mathbf{R}_{b}^{m}(t)$ - time-dependent rotation matrix between the b-frame and the $\mathrm{m}$-frame, measured by INS,

$\mathbf{R}_{c}^{b} \quad$ - rotation matrix between the c-frame and the b-frame, defined in the INS coordinate frame,

$s_{i} \quad$ - scale factor,

$r^{c} \quad$ - coordinate of the vector (in the c-frame)

$a^{b} \quad$ - distance between INS and the camera.

This relation assumes that IMU is tightly fixed to the vehicle body, in the way that the bframe is defined by the INS sensor frame. The rotation matrix $\mathbf{R}_{c}^{b}$ is given by the expression:

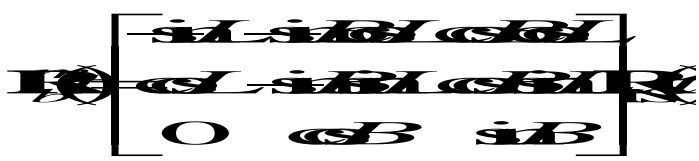

where $B$ is the geodetic latitude, $L$ the geodetic longitude and $\mathbf{R}_{\mathrm{INS}}(t)$ the rotation matrix, consisted of the angles of direction, slope, and torsion (i.e., the rotation angles about $Z, Y$ and $X$ axes, respectively).

The digital cameras are synchronized, in order to take the photos in the same time. Those photos can be easily geo-referenced, thanks to GNSS/INS on the vehicle and the construction that mutually connects all the sensors. The cameras, according to the 
Contemporary achievements in civil engineering 21. April 2017. Subotica, SERBIA

photogrammetry theory, are used for obtaining 3D spatial coordinates of the objects. To accomplish that, each object has to be photographed by two cameras at least, from two separate known spots. Although it is possible to obtain the position using only one photo, for better accuracy of the surveying, stereo photogrammetry is used. While the classical photogrammetry is based on adjusting the directions in order to get the six elements of the external orientation, the systems for mobile mapping can calculate these values directly from the GNSS/INS sensors.

When the objects are photographed, the system is used for identification of the objects in the area of surveying. While the older systems have used the manual methods of the objects identification, today many of the systems recognize the objects automatically or semi-automatically. It is done very successfully by using techniques of the image processing, especially in the case of the linear objects, and other characteristics with a recognizable geometrical shape.

\section{APPLICATION OF MMS IN THE PROJECT OF PRODUCING THE CADASTRE OF THE TRAFFIC SIGNALING}

The mentioned system for the modern approach of the spatial data acquisition, found its very wide scope of application. Depending on the application, in certain projects, this technology is the most efficient, high-quality and the cheapest method of the spatial data collection.

One of such projects is, certainly, the project of the cadastre of the traffic signaling. Geodetic surveying, producing the spatial background and collecting all the spatial and alpha-numerical data about traffic signaling and fittings, was mostly a challenge in the traditional approach. The geodetic phase in such multi-disciplinary projects was, mostly, unacceptably expensive and lasted very long. Interpretation of the spatial data in the form of the standard topographic or cadastral maps was usually non-adequate for the users of the spatial information. Application of MMS has brought revolutionary changes in the mentioned projects, as an efficient, with an acceptable price and reliable way of collecting spatial information. It allows fast processing of the field data, interpretation in the form of geo-referenced digital spherical photos, 3D point clouds and a number of meta data. The user can extract the spatial data, transfer them into databases or graphical environments. The integration with all existing geo-referenced spatial data is possible: a digital cadastre map, an ortho-photo map, the vector data from the technical documentation, etc.

The projects of producing the cadastre of the traffic signaling, depending on the project task and needs of an investor, are based mainly on collecting the spatial data about the vertical and horizontal traffic signaling, the spatial geometry of the streets network, as well as, storing side content of the street fittings.

Despite of the level of detail and the structure of the database of the cadastre of the traffic signaling, a common place for all the projects are spatial information, i.e., attributes of the traffic signaling, which are necessary to be surveyed by the geodetic methods, and then to integrate them into the cadastre of the traffic signaling.

\subsection{Spatial data structure in the database of the traffic signaling}


We are presenting here the example of the database structure of the cadastre of the traffic signaling, using the data from the project realized for the needs of the Secretary for traffic of the City of Belgrade.

The integrated, complete and well structured system, defined by the project task of the investor, assumed collecting and processing of the spatial data, as well as creating the database of the traffic signaling elements. The complex structure of the database will be presented here on the example of one of its thematic parts, explaining the quantity of data that could be collected directly, using the products of MMS.

Table 1. Attribute structure of the table "Traffic sign"

\begin{tabular}{|c|c|c|c|}
\hline $\begin{array}{l}\mathrm{N} \\
\mathrm{O}\end{array}$ & Attribute & Data type & Attribute value \\
\hline$\bullet$ & FID & Object ID & $\begin{array}{l}\text { Automatically generated } \\
\text { value }\end{array}$ \\
\hline$\bullet$ & ID_znaka & $\begin{array}{l}\text { Long integer } \\
\text { PRIMARY_KEY }\end{array}$ & Set ID \\
\hline$\bullet$ & $\begin{array}{l}\text { Položaj_znaka_smer } \\
\text { kretanja }\end{array}$ & Text (255 Char) & $\begin{array}{l}\text { Direction of the sign face } \\
\text { related to the direction of } \\
\text { moving }\end{array}$ \\
\hline$\bullet$ & Broj_Nosača_Znaka & Long integer & $\begin{array}{l}\text { Number of the support } \\
\text { carrying the sign: }(1,2,3 . .)\end{array}$ \\
\hline$\bullet$ & $\begin{array}{l}\text { ID_glavnog_nosača_saobr } \\
\text { aćajnog_znaka_1 }\end{array}$ & $\begin{array}{l}\text { Long integer } \\
\text { FOREIGN_KEY }\end{array}$ & ID of the traffic sign support \\
\hline$\bullet$ & $\begin{array}{l}\text { Tip_glavnog_nosača_saobr } \\
\text { aćajnog_znaka_1 }\end{array}$ & Text (255 Char) & $\begin{array}{l}\text { Text description of the } \\
\text { support according to } \\
\text { ID_glavnog_nosača_saobrać } \\
\text { ajnog_znaka_1 }\end{array}$ \\
\hline - & $\begin{array}{l}\text { ID_glavnog_nosača_saobr } \\
\text { aćajnog_znaka_2 }\end{array}$ & $\begin{array}{l}\text { Long integer } \\
\text { FOREIGN_KEY }\end{array}$ & Value:Default: 0 \\
\hline$\bullet$ & $\begin{array}{l}\text { Tip_glavnog_nosača_saobr } \\
\text { aćajnog_znaka_2 }\end{array}$ & Text (255 Char) & $\begin{array}{l}\text { Text description of the } \\
\text { support according to } \\
\text { ID_glavnog_nosača_saobrać } \\
\text { ajnog_znaka_2 }\end{array}$ \\
\hline$\bullet$ & $\begin{array}{l}\text { ID_pomoćnog_nosača_sao } \\
\text { braćajnog_znaka_1 }\end{array}$ & $\begin{array}{l}\text { Long integer } \\
\text { FOREIGN_KEY }\end{array}$ & Value:Default: 0 \\
\hline$\bullet$ & $\begin{array}{l}\text { Tip_pomoćnog_nosača } \\
\text { saobraćajnog_znaka_1 }\end{array}$ & Text (255 Char) & $\begin{array}{l}\text { Text description of the } \\
\text { support }\end{array}$ \\
\hline$\bullet$ & ID_deonice & $\begin{array}{l}\text { Long integer } \\
\text { FOREIGN_KEY }\end{array}$ & ID of the segment (link) \\
\hline • & ID_kolovoza & $\begin{array}{l}\text { Long integer } \\
\text { FOREIGN_KEY }\end{array}$ & ID of the driveway \\
\hline$\bullet$ & ID_opštine & $\begin{array}{l}\text { Long integer } \\
\text { FOREIGN_KEY }\end{array}$ & $\begin{array}{l}\text { taken from the Table No. 1: } \\
\text { segment (link) }\end{array}$ \\
\hline$\bullet$ & Naziv_opštine & $\begin{array}{l}\text { Text (50 Char) } \\
\text { FOREIGN_KEY }\end{array}$ & Municipality name \\
\hline
\end{tabular}


Contemporary achievements in civil engineering 21. April 2017. Subotica, SERBIA

\begin{tabular}{|c|c|c|c|}
\hline$\bullet$ & Šifra_ulice & $\begin{array}{l}\text { Long_integer } \\
\text { FOREIGN_KEY }\end{array}$ & $\begin{array}{l}\text { taken from the Table No. 1: } \\
\text { segment (link) }\end{array}$ \\
\hline • & Naziv ulice & Text (255 Char) & Name of the street \\
\hline$\bullet$ & Šifra_saobraćajnog_znaka & Long integer & According to the regulation \\
\hline$\bullet$ & $\begin{array}{l}\text { Š́ifra_saobraćajnog_znaka } \\
\text { _ }\end{array}$ & $\begin{array}{l}\text { Long integer } \\
\text { FOREIGN_KEY }\end{array}$ & $\begin{array}{l}\text { More precise description of } \\
\text { the traffic sign }\end{array}$ \\
\hline$\bullet$ & Dopunska_tabla & $\begin{array}{l}\text { Long_integer } \\
\text { FOREIGN_KEY }\end{array}$ & $\begin{array}{l}\text { Description of a possible } \\
\text { auxiliary traffic sign }\end{array}$ \\
\hline$\bullet$ & Redno_mesto_na_stubu & Double & $\begin{array}{lrr}\text { serial number. } & \text { Possible } \\
\text { values: } 1,2,3,4,5 & \\
\end{array}$ \\
\hline$\bullet$ & Visina_gornje_ivice_znaka & & $\begin{array}{l}\text { Measured height of the upper } \\
\text { side of the sign }\end{array}$ \\
\hline$\bullet$ & Visina_donje_ivice_znaka & Long integer & $\begin{array}{l}\text { Measured height of the lower } \\
\text { side of the sign }\end{array}$ \\
\hline$\bullet$ & Oblik_znaka & Text (50 Char) & Shape of the sign \\
\hline$\bullet$ & Osvetljenje_znaka & Text (250 Char) & Type of the sign illumination \\
\hline$\bullet$ & Materijal_izrade & hyperlink & $\begin{array}{l}\text { Material that the traffic sign } \\
\text { is made of }\end{array}$ \\
\hline$\bullet$ & Lice_znaka & Long integer & $\begin{array}{l}\text { Class of the material of the } \\
\text { sign's face }\end{array}$ \\
\hline$\bullet$ & Koeficijent_retrorefleksije & & 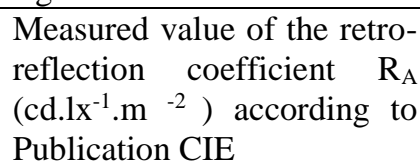 \\
\hline$\bullet$ & $\begin{array}{l}\text { Usklađenost_SRPS_ } \\
\text { EN_12899-1:2011 }\end{array}$ & Long integer & $\begin{array}{l}\text { Corresponds to ISO-SRPS } \\
\text { 12899-1:2011 (Yes/No) }\end{array}$ \\
\hline$\bullet$ & Boja_osnove_znaka & Long integer & $\begin{array}{l}\text { Description of the sign's base } \\
\text { color, according to } \\
\text { regulations }\end{array}$ \\
\hline$\bullet$ & Dimenzije_znaka_1 & Formula & Dimensions of the sign 1 \\
\hline$\bullet$ & Dimenzije_znaka_2 & Long integer & Dimensions of the sign 2 \\
\hline$\bullet$ & Površina_znaka & & $\begin{array}{l}\text { Calculated value of the sign's } \\
\text { area }\end{array}$ \\
\hline$\bullet$ & Poleđina_znaka & Raster & Boja poleđine znaka \\
\hline$\bullet$ & Tip_kačenja & Double & $\begin{array}{l}\text { 1. Šelna } \\
\text { 2. Perforirana traka }+ \text { Šelna }\end{array}$ \\
\hline$\bullet$ & Fotografija_znaka & Double & $\begin{array}{lrrr}\text { Format u } & \text { saradnji } & \text { sa } \\
\text { Naručiocem } & & \end{array}$ \\
\hline$\bullet$ & $\mathbf{X}$ & Double & $\mathrm{X}$ koordinata centra znaka \\
\hline$\bullet$ & $\mathrm{Y}$ & Double & Y koordinata centra znaka \\
\hline$\bullet$ & $\mathrm{Z}$ & Double & Z koordinata centra znaka \\
\hline$\bullet$ & $\mathrm{Z1}$ & Double & $\begin{array}{l}\text { Z1 koordinata donje ivice } \\
\text { znaka }\end{array}$ \\
\hline
\end{tabular}


Савремена достигнућа у грађевинарству 21. април 2017. Суботица, СРБИЈА

\begin{tabular}{|r|l|l|l|}
\hline$\bullet$ & Z2 & Date & $\begin{array}{l}\text { Z2 koordinata gornje ivice } \\
\text { znaka }\end{array}$ \\
\hline$\bullet$ & Rotacija & Date & Usmerenost znaka \\
\hline$\bullet$ & Datum snimanja & $\begin{array}{l}\text { Text } \\
(255 \text { ch. })\end{array}$ & Dd/mm/jjjj \\
\hline$\bullet$ & Datum unosa & & Dd/mm/jjjj \\
\hline$\bullet$ & Napomene & \multicolumn{2}{|l}{} \\
\hline
\end{tabular}

Table 1 shows the integrated and the very complex attribute model, describing the theme "traffic sign" in the mentioned database. Almost all the data from the table can be populated with information found in the spherical photos and the point cloud. Fig. 3 depicts a part of the database and the way of interpretation of the mentioned attributes on the spatial background.

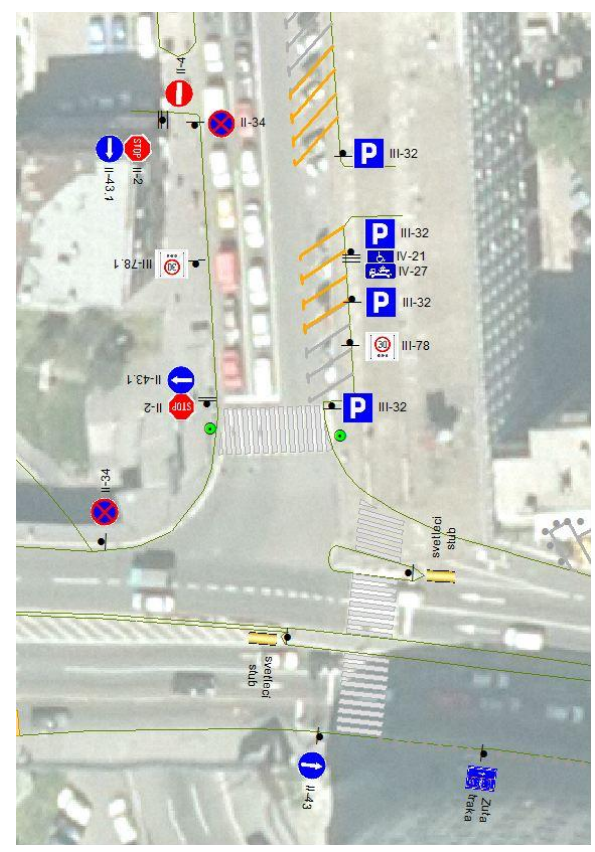

Figure 2. Recast of the traffic signaling (layer "Traffic sign")

\section{CONCLUSION}

MMS, thanks to its functional characteristics described in this paper, represents a very effective, reliable, and high-quality system for the spatial data acquisition. The application fields of this technology, collecting and processing the spatial data, fit to various engineering-technical projects. Within the scope of the project of the cadastre of the traffic signaling, the possibility of its usage is approved. The projects realized recently, 


\section{$5^{\text {th }}$}

INTERNATIONAL CONFERENCE

Contemporary achievements in civil engineering 21. April 2017. Subotica, SERBIA

undoubtedly approved that the mentioned technology is the most efficient, economically effective and the most reliable in the procedure of collecting spatial data, regarding the realization of the projects of the cadastre of traffic signaling.

\section{REFERENCES}

[1] Kuburić, M., Kopić, M., Matić, B.: Contemporary methods of spatial data acquisition - the road to «e-government», Geodetski vestnik, 2014., str. 314, do str. 326, DOI: 10.15292/geodetskivesnik.2014.02.314326

[2] http://www.geohide.com/data/file/IP_S2_6PG.pdf, download 01.03.2017.

[3] http://www.navicom.hu/files/IP-S2-munkafolyamat.pdf, download 01.03.2017. 